\title{
Evaluation of Tomato Cultivars for Yield, Profitand Quality Performance in an Organic Management System in North Western Himalayas, India
}

\author{
D.K. Parmar, D.R. Thakur, R.S. Jamwal and Gurudevsingh
}

\author{
CSK Himachal Pradesh Krishi Vishvavidayalaya, Hill Agricultural Research and Extension \\ Centre, Bajaura 175125, District Kullu, India
}

*Corresponding author

\section{Keywords}

Tomato cultivars, Yield,

Prifit, Quality, Organic

management, North

western Himalayas, India

Article Info

Accepted:

06 September 2018

Available Online:

10 October 2018

\section{A B S T R A C T}

To study the performance of different tomato cultivars under organic regimes, an experiment was conducted from 2013 - 2015at the experimental farm of the Himachal Pradesh Agricultural University, Hill Agricultural Research and Extension Centre, Kullu, India. Among different cultivars, Sioux variety took maximum days (74) from transplanting to first harvest and HeemSohna hybrid took minimum time of 67.2 days. The maximum plant height was observed in hybrid RK $123(100.6 \mathrm{~cm})$ followed by Best of all $(100.3 \mathrm{~cm})$. The minimum height was recorded for Sioux $(83.9 \mathrm{~cm})$. The Red gold hybrid recorded significantly highest number of fruits per plant (25.9) followed by RK 123 (20.0). The Red Gold hybrid had greater fruit size $\left(29.0 \mathrm{~cm}^{2}\right)$ followed by RK $123\left(26.4 \mathrm{~cm}^{2}\right)$, HeemSohna $\left(24.6 \mathrm{~cm}^{2}\right)$, Palam Pink $\left(23.3 \mathrm{~cm}^{2}\right)$ and Mar Globe $\left(22.9 \mathrm{~cm}^{2}\right)$, whereas the fruit size of Best of All $\left(18.8 \mathrm{~cm}^{2}\right)$ and Naveen $2000\left(19.2 \mathrm{~cm}^{2}\right)$ was minimum. Some of the entries of tomato namely RK 123, Manisha, Best of all Yash, Naveen 2000, Red Gold hybrid recorded highest but similar TSS content as compared to rest of the hybrids/varieties. All hybrids had highest but statistically similar acidity ranging from $0.54-0.58 \mathrm{~g} / 100 \mathrm{ml}$ of juice but varieties recorded significantly lower value of acidity (0.41-0.46 g/100 ml of juice). The ascorbic acid contents within hybrids and varieties were identical, though hybrids recorded higher ascorbic acid values (18.53-22.08 g/100 ml of juice) than varieties (11.53- $14.52 \mathrm{~g} / 100 \mathrm{ml}$ of juice). The hybrids contained lower carotene and lycopene as compared to varieties. The hybrid Manisha recorded minimum carotene and lycopene content $(5.25 \mathrm{mg} / 100 \mathrm{~g}$ of fruit and $3.90 \mathrm{mg} / 100 \mathrm{~g}$ of fruit) and highest was in Best of All variety $(9.51 \mathrm{mg} / 100 \mathrm{~g}$ and $6.38 \mathrm{mg} / 100 \mathrm{~g}$ of fruit). Red Gold hybrid produced maximum tomato fruits $(143.7 \mathrm{q} / \mathrm{ha})$ and minimum fruit yield was recorded for Best of all (33.7 q/ha) and Marglobe (34.7 q/ha). Significantly higher profit and B: C was observed in case of Red Gold hybrid (rupees 259685/ha and 1.37) followed by RK 123 (rupees 186497/ha and 0.99), however, rest of the entries were found to be non-profitable.

\section{Introduction}

Tomato is grown worldwide for its edible fruits, with antioxidants benefits. It has been reported that consumption of raw tomato and tomato based products is associated with reduced risk of cancer and cardiovascular disease (Giovannucci et al., 2002). The organic production system aims at supporting and sustaining healthy eating habits, 
ecosystems, soil, farmers, community, and the economy. There are rising numbers of customers who are in search of healthier, tastier and environmentally friendly food, increasing the demand for organic produce. A large proportion of commercially grown tomato have been developed and adapted to conventional agriculture systems, which employ synthetic chemicals in its culture (Brady 2011; Santos et al., 2013). Performance of cultivars developed for conventional cropping systems differ in organic production system (Ahmad et al., 2007; Murphy et al., 2007). Organic cropping system is an alternative to develop organic tomato cultivars which can be adapted to local conditions and produce higher yields under organic management (Nandwani et al., 2014; Colley and Myers, 2007; Palada and Davis, 2001). The objective of this study was to evaluate the yield performance and other agronomic characteristics of tomato cultivars grown in organic management systems.

\section{Materials and Methods}

The study site, Himachal Pradesh Krishi Vishvavidyalaya Hill Agricultural Research \& Extension Center, Bajaura, Kullu, India, is located at $31.8^{\mathrm{O}} \mathrm{N}$ latitude, $77^{\mathrm{O}} \mathrm{E}$ longitude in the Northwestern Himalayas, a part of India in Himachal Pradesh State. The area receives an average annual rainfall of $1530 \mathrm{~mm}$. The area has average maximum and minimum temperatures of $26.2^{\circ} \mathrm{C}$ and $11.3^{\circ} \mathrm{C}$, respectively. Field experiments on tomato were carried out during summer. Tomato cultivars (seven varieties and five hybrids) were used in the experiment.

The experimental plots were laid out in a randomized block design (RBD) with three replications. The seeds of all varieties were obtained from the germplasm collections maintained at Centre and hybrids were purchased from the local market.
The study was conducted under irrigation during the 2013, 2014 and 2015 cropping seasons. Seedlings of tomato were raised in nursery beds of $2 \mathrm{~m} \times 1 \mathrm{~m}$ in size, raised $5 \mathrm{~cm}$ from the soil surface to provide good drainage for the removal of surplus irrigation water. The seeds were sown in rows spaced $15 \mathrm{~cm}$ apart and covered lightly with fine soil before irrigation.

The beds were irrigated every day until germination then twice a week. After germination, seedlings were thinned until an intra-row spacing of $3 \mathrm{~cm}$ was achieved.

Seedlings were carefully transplanted after 6 weeks to the experimental plots which were prepared with $2.0 \mathrm{~m} \times 3.2 \mathrm{~m}$ dimensions to accommodate 28 plants per plot (four rows) at a recommended spacing of $90 \mathrm{~cm}$ between rows and $30 \mathrm{~cm}$ between plants. The spacing between two plots in each replication and between adjacent blocks was $0.5 \mathrm{~m}$ and $1 \mathrm{~m}$, respectively as an aisle.

The crop was supplied with a mix of FYM and vermicompost equivalent to recommended NPK fertilizers. Standard agronomic practices such as weeding, cultivation, irrigation, organic fertilizer application and staking were carried out uniformly during the growing season for all plots. Diseases and insects were managed using bio agents. Fruits were harvested at the mature green stage.

Field data were collected in this experiment including growth parameters, plant characters, yield components, fruit yield and fruit quality as indicated next.

\section{Plant height}

Plant height was recorded by measuring the height of five randomly selected plants in each plot from the ground level to the main apex; mean values were expressed in $\mathrm{cm}$. 


\section{Number of fruits per plant}

The total number of fruits per plant was counted from each five pre-tagged plant in each plot having.

\section{Marketable fruit yield}

At each harvest, fruits were categorized as marketable or unmarketable fruits.

Fruits with cracks, damaged by insects, diseases, birds, small fruits and those with sunburn were considered as unmarketable and fruits free from visible damage were considered as marketable and yield was expressed in terms of $\mathrm{q} / \mathrm{ha}$.

\section{Average equatorial fruit diameter}

The same fruit which was used for polar diameter was measured for their equatorial (trans-verse diameter) diameter; values were expressed in $\mathrm{cm}$.

\section{Produce quality}

\section{TSS}

The TSS content of fruits was measured on Refractometer.

\section{Titratable acidity}

Two milliliter of juice was titrated against 0.1 $\mathrm{N}$ sodium hydroxide $(\mathrm{NaOH})$ using phenolphthalein as an indicator. Appearance of pink colour was taken as end point of titration.

Titratable acidity was expressed in terms of $\mathrm{mg}$ anhydrous citric acid in $100 \mathrm{ml}$ of juice and calculated as follows:

Titratable acidity $=\mathrm{Vol}$. of $\mathrm{NaOH} / \mathrm{Vol}$. of juice taken $\times 0.0064 \times 100$

\section{Ascorbic acid (mg/100 ml)}

It was estimated by 2,6-dichlorophenol indophenol method of AOAC (1975). Two milliliter juice sample was added to an equal volume of $6 \%$ metaphosphoric acid in a conical flask and titrated with standard dye solution. The end point was indicated by the appearance of pink colour, which persisted for about $15 \mathrm{~s}$. The dye was standardized with standard stock solution $(1 \mathrm{mg} / 1 \mathrm{ml})$ of ascorbic acid. The results were expressed as milligrams ascorbic acid/100 $\mathrm{ml}$ of tomato juice and calculated as follows:

Ascorbic acid $=\mathrm{Y} / \mathrm{X} \times 100$

Where, $\mathrm{Y}$ is the volume of dye used $(\mathrm{ml})$ in titrating $2 \mathrm{ml}$ juice and $\mathrm{X}$ the volume of dye used (ml) in titrating $2 \mathrm{ml}$ standard stock solution.

\section{Lycopene (mg/100 g)}

Two gram fruit sample was taken and pigment was extracted with $10 \mathrm{ml}$ acetone in portions, using $2 \mathrm{ml}$ at a time until a colourless residue was obtained. The acetone was evaporated to dryness. The volume was brought to $25 \mathrm{ml}$ with petroleum ether. The optical density was read at $505 \mathrm{~nm}$ (since $\beta$ carotene has negligible absorbance at this wavelength) using a Systronics Spectrophotometer. Petroleum ether was used as blank. Lycopene content was calculated as:

Lycopene content $=$ Final vol. $(\mathrm{ml}) \times$ Optical density $/ 2 \times$ Wt. of sample $(\mathrm{g})$

\section{Statistical analysis}

The data were subjected to ANOVA for a randomized block design and means were compared using significant difference at 5\% probability using CPCS-1 data analysis package. 


\section{Results and Discussion}

\section{Days to harvest}

Analysis of data showed significant differences among the varieties/hybrids for number of days taken to first harvest (Table 1). The Sioux variety of tomato took maximum days (74) from transplanting to first harvest and HeemSohna hybrid was bit early and took minimum time of 67.2 days. However, other cultivars had similar period to first harvest. Other studies (Abrar et al., 2011 and Falak et al., 2011) showed that the time taken from transplanting to first harvest for tomato cultivars ranged between 70 and 120 days. Moraru et al., (2004) also indicated a wide range of variability in days to first harvest.

\section{Plant height}

In the present study, maximum but similar plant height was observed in hybrid RK 123 $(100.6 \mathrm{~cm})$ and Best of all $(100.3 \mathrm{~cm})$. However, their height was statistically at par with other varieties/hybrids except Sioux which had minimum height $(83.9 \mathrm{~cm})$ (Table $1)$. These findings agreed with that of Jamala et al., (2011), who reported that taller okra plants were obtained at maximum temperature of 25 to $35^{\circ} \mathrm{C}$. High maximum temperature was experienced during the vegetative growth and consequently more assimilates production occurred which probably induced better plant growth and yield in hot season. Similar opinion was put forwarded by Hossain et al., (2002) in brinjal and Mehraj et al., (2014) in tomato who reported that growth and development of crops can be influenced by season.

\section{No. of fruits/plant}

The Red gold hybrid recorded significantly highest number of fruits per plant (25.9) followed by RK 123 (20.0). The Mar Globe, Manisha, Best of all and Yash hybrids bear minimum and similar fruits per plant (13.0, 13.5, 13.6 and 14.5). Hybrid namely 7730, Roma, Sioux, Naveen 2000 had similar number of fruits per plant but significantly lower than Red Gold and RK 123 but higher than Mar Globe, Manisha, Best of all and Yash hybrids (Table 1). Organic regimes having many nutrients (balance nutrients), which are responsible for development of flowers and fruits, while inorganic only NPK. The number of fruits per plant may increase due to the more number of flowers remained on the plant and increased the chances to form more fruits by the plants treated with organic manures and also due to varietal differences among the different cultivars. According to Tonfack et al., (2009), the increase in number of fruits in tomato may be due to carbon contents, and increase cation exchange capacity of soil, which added to the development of fruit formation and also less pest and disease attack on plants treated with organic fertilizers.

\section{Fruit size}

The tomato fruit size varied significantly among different varieties/hybrids (Table 1). The Red Gold hybrid had greater fruit size $\left(29.0 \mathrm{~cm}^{2}\right)$ followed by RK $123\left(26.4 \mathrm{~cm}^{2}\right)$, HeemSohna $\left(24.6 \mathrm{~cm}^{2}\right)$, Palam Pink (23.3 $\mathrm{cm}^{2}$ ) and Mar Globe $\left(22.9 \mathrm{~cm}^{2}\right)$, whereas the fruit size of Best of All $\left(18.8 \mathrm{~cm}^{2}\right)$ and Naveen $2000\left(19.2 \mathrm{~cm}^{2}\right)$ was minimum. Except two hybrids namely Red Gold and RK 123, all other varieties/hybrids were statistically at par with each other. The increment in the fruit size may be due to organic fertilizer that provided calcium and potassium in proper amount with appropriate water absorbed by the plants, which caused elongation in the size of tomato fruits. Masarirambi et al., (2009) observed similar results while working on tomato plant and concluded that the enlargement of tomato 
fruit size might be due to physiological fitness and manure application, which influenced all growth parameters. In addition organic fertilizers were found better than application of inorganic fertilizer because inorganic provided NPK while manures provided full supplement.

\section{Fruit quality}

\section{TSS}

Some of the entries of tomato namely RK 123, Manisha, Best of all Yash, Naveen 2000, Red Gold recorded highest but similar TSS content as compared to rest of the hybrids/varieties (Table 2). The organic manures have been proved beneficial in enhancing the fruit quality of tomato. Similar results were also observed by Zhu-wei Min et al., (2003) that tomato cultivar 'Puhong 909' had maximum TSS content $(4.5 \%)$ under the multispan greenhouse. Singh (2011) also reported that maximum TSS was present in 'Naveen' (5.60) under naturally ventilated polyhouse. The value of total soluble solids content varied from $4.79 \%$ to $6.02 \%$ (Hossain et al., 2010). Durvesh and Singh (2006); Ahmad et al., (2012); Gupta et al., (2011) reported that quality attributes like total soluble solids of the fruit ranged from 3.67 to $6.0^{\circ} \mathrm{Brix}$.

\section{Acidity}

Acidity of tomato fruits has great significance from processing point of view. According to Guold and Berry (1972), a tomato variety for processing should have acid contents ranging from $0.35 \%$ to $0.55 \%$. High acidity prevents microbial activities in processed products.

During three years of study, all the hybrids have highest but statistically similar acidity ranging from $0.54-0.58 \mathrm{~g} / 100 \mathrm{ml}$ of juice but varieties recorded significantly lower value of acidity (0.41-0.46 g/100 ml of juice) (Table 2). Similar results were also reported by Hossain et al., (2010) and Singh (2011).

Table.1 Mean growth, yield attributes, fruit quality and yield of tomato hybrids/varieties (average of 3 years)

\begin{tabular}{|l|c|c|c|c|}
\hline Hybrid/variety & $\begin{array}{c}\text { Plant height } \\
(\mathbf{c m})\end{array}$ & $\begin{array}{c}\text { No. of fruits/ } \\
\text { plant }\end{array}$ & $\begin{array}{c}\text { Days taken to } \\
\text { harvest }\end{array}$ & Fruit size $\left(\mathrm{cm}^{2}\right)$ \\
\hline Yash*** & 95.6 & 14.5 & 70.7 & 21.1 \\
\hline Naveen2000** & 99.6 & 18.3 & 70.9 & 19.2 \\
\hline Manisha*** & 99.6 & 13.5 & 71.1 & 20.7 \\
\hline Red Gold*** & 99.0 & 25.9 & 71.7 & 29.0 \\
\hline Hybrid 7730*** & 98.7 & 18.0 & 68.7 & 23.5 \\
\hline Roma* & 93.8 & 18.5 & 70.9 & 22.0 \\
\hline Sioux* & 83.9 & 18.3 & 74.0 & 20.9 \\
\hline Best of all** & 100.3 & 13.6 & 71.0 & 18.8 \\
\hline Palam Pink** & 99.1 & 14.1 & 69.9 & 23.3 \\
\hline Mar Globe* & 94.7 & 13.0 & 70.0 & 22.9 \\
\hline RK 123** & 100.6 & 20.0 & 69.8 & 26.4 \\
\hline HeemSohna*** & 99.7 & 18.6 & 67.2 & 24.6 \\
\hline CD (5\%) & 5.0 & 2.1 & 2.01 & 1.3 \\
\hline
\end{tabular}

*Variety, ** Hybrid 
Table.2 Mean Fruit quality of tomato hybrids/varieties

\begin{tabular}{|c|c|c|c|c|c|}
\hline Hybrid/variety & TSS ( ${ }^{1}$ Brix) & $\begin{array}{c}\text { Acidity } \\
\text { (g/100 ml of } \\
\text { juice) }\end{array}$ & $\begin{array}{l}\text { Ascorbic } \\
\text { acid (g/100 } \\
\text { ml of juice) }\end{array}$ & $\begin{array}{l}\text { Carotene } \\
\text { (mg/100 } \mathrm{g} \text { of } \\
\text { fruit) }\end{array}$ & $\begin{array}{l}\text { Lycopene } \\
\text { (mg/100 } \mathrm{g} \text { of } \\
\text { fruit) }\end{array}$ \\
\hline Yash*** & 4.3 & 0.58 & 20.15 & 6.54 & 4.14 \\
\hline Naveen2000***; & 4.1 & 0.58 & 18.53 & 6.35 & 3.90 \\
\hline Manisha*** & 4.3 & 0.57 & 21.57 & 5.25 & 4.48 \\
\hline Red Gold*** & 4.2 & 0.56 & 22.08 & 6.15 & 4.15 \\
\hline Hybrid 7730** & 3.8 & 0.54 & 20.05 & 6.40 & 4.36 \\
\hline Roma* & 4.8 & 0.46 & 14.52 & 8.34 & 5.38 \\
\hline Sioux* & 4.6 & 0.42 & 12.45 & 8.47 & 5.95 \\
\hline Best of all* & 5.1 & 0.44 & 13.58 & 9.51 & 6.88 \\
\hline Palam Pink* & 4.8 & 0.41 & 12.20 & 6.56 & 5.90 \\
\hline Mar Globe* & 4.8 & 0.44 & 11.53 & 8.27 & 6.64 \\
\hline RK 123** & 4.4 & 0.56 & 21.30 & 5.38 & 5.24 \\
\hline HeemSohna*** & 4.1 & 0.58 & 21.45 & 6.00 & 5.40 \\
\hline CD (5\%) & 0.40 & 0.10 & 4.11 & 1.04 & 1.03 \\
\hline
\end{tabular}

*Variety, ** Hybrid

Table.3 Mean tomato yield and profitability of hybrids/varieties under organic nutrient management

\begin{tabular}{|l|c|c|c|c|c|}
\hline Hybrid/variety & $\begin{array}{c}\text { Yield } \\
\text { (q/ha) }\end{array}$ & $\begin{array}{c}\text { Gross } \\
\text { Returns }\end{array}$ & $\begin{array}{c}\text { Cost of } \\
\text { Cultivation }\end{array}$ & Net Returns & B:C \\
\hline Yash*** & 79.0 & 246875 & 185628 & 61247 & 0.33 \\
\hline Naveen2000*** & 60.3 & 188438 & 187128 & 1310 & 0.01 \\
\hline Manisha*** & 110.3 & 344688 & 186183 & 158505 & 0.85 \\
\hline Red Gold*** & 143.7 & 449063 & 189378 & 259685 & 1.37 \\
\hline Hybrid 7730*** & 117.3 & 366563 & 185703 & 180860 & 0.97 \\
\hline Roma* & 64.6 & 201875 & 184458 & 17417 & 0.09 \\
\hline Sioux* & 47.6 & 148750 & 184458 & -35708 & -0.19 \\
\hline Best of all*** & 33.7 & 105313 & 184458 & -79146 & -0.43 \\
\hline Palam Pink* & 60.7 & 189688 & 184458 & 5230 & 0.03 \\
\hline Mar Globe** & 34.7 & 108438 & 184458 & -76021 & -0.41 \\
\hline RK 123*** & 119.8 & 374375 & 187878 & 186497 & 0.99 \\
\hline HeemSohna*** & 115.7 & 361563 & 189378 & 172185 & 0.91 \\
\hline CD (0.05) & 9.2 & - & - & 61247 & 0.31 \\
\hline
\end{tabular}

*Variety, ** Hybrid

\section{Ascorbic acid}

High ascorbic acid in tomato aids in better retention of natural colour and flavour of the products (Thamburaj, 1998). There were significant differences for ascorbic acid content in hybrids and varieties (Table 2). However, the ascorbic acid contents within 
hybrids and varieties were identical, though hybrids recorded higher ascorbic acid values (18.53-22.08 g/100 $\mathrm{ml}$ of juice) than varieties (11.53- $14.52 \mathrm{~g} / 100 \mathrm{ml}$ of juice). Singh (2011) also reported that 'ARTH-128' recorded maximum ascorbic acid content (20.63) and 'To-Ind-Hyb/4' recorded minimum ascorbic acid content (14.03) under net/poly house. Similar to this study Gupta et $a l$. , (2011) reported that ascorbic acid content ranged from 19.88 to $27.68 ; 19.50$ to 30.06 and 27.82 to $31.33 \mathrm{mg}$ per $100 \mathrm{~g}$ in different tomato genotypes.

\section{Carotene}

As far as carotene content is concerned, there were significant differences among hybrids and varieties (Table 2). The hybrids have low value of carotene as compared to hybrids. Best of all variety a recorded maximum carotene content $(9.51 \mathrm{mg} / 100 \mathrm{~g}$ of fruit) and lowest was in Manishahybrid $(5.25 \mathrm{mg} / 100 \mathrm{~g}$ of fruit). Singh (2011) observed maximum carotene content in 'NP-1001' (4.11). Data corresponds to earlier study by Gupta et al., (2011), who reported $\beta$-carotene content range from 4.80 to 5.30 and 5.40 and $6.78 \mathrm{mg}$ per $100 \mathrm{~g}$ in different tomato genotypes.

\section{Lycopene}

Lycopene is one of major character controlling the fruit colour which affects the quality of tomato. There were significant differences for lycopene content among hybrids and varieties (Table 2).

The highest value for lycopene was observed in Best of all variety $(6.38 \mathrm{mg} / 100 \mathrm{~g}$ of fruit and lowest in hybrid Naveen $(3.90 \mathrm{mg} / 100 \mathrm{~g}$ of fruit). Data corresponds to earlier study by Gupta et al., (2011), who reported lycopene content range from 1.40 to 4.15 and 3.23 to $4.03 \mathrm{mg}$ per $100 \mathrm{~g}$ in different genotypes of tomato.

\section{Yield and net profit}

\section{Fruit yield}

The data demonstrated that Red Gold hybrid produced maximum tomato fruits (143.7 q/ha) and minimum fruit yield was recorded for Best of all (33.7 q/ha) and Marglobe (34.7 $\mathrm{q} / \mathrm{ha}$ ). The next highest fruit yield was observed for RK 123 (119.8 q/ha) followed by 7730 (117.3 q/ha), HeemSohna (115.7 q/ha) and Manisha (110.3 q/ha) were however, statistically similar to each other (Table 3). The increase and decrease in tomato yield may be due to the genetic potential of each cultivar and also the application of organic manure might have brought about positive change in the total yield by supplementing the essential elements for tomato plants. According to Palm et al., (1997), recommended dose of organic manure can be used by plants for contributing effectively to all growth parameters and enhance the growth and yield of tomatoes.

The result of Akanbi et al., (2005) is of primary importance to these findings as they concluded that application of organic manure and compost was responsible for achieving desirable growth and yield parameters in tomato plants. The gain in fruit weight may be due to the genetic attributes of different tomato cultivars and may also be due to formation of fruit on healthy plants, which utilized more nutrients, water and light according to requirement for more production. Unlu and Padem (2009) reported that farm yard manure was better than NPK as more fruit weight was recorded in tomato plants treated with organic manure as compared to inorganic fertilizer because organic manure have more water-holding capacity and provide continuous nutrients, which is in accordance with these result for more accumulation of weight in tomato plants treated with organic fertilizer. 


\section{Net returns}

The net returns and benefit cost ratio for different hybrids/varieties varied significantly and maximum profit and B: C was observed in case of Red Gold hybrid (rupees 259685/ha and 1.37) followed by RK 123 (rupees 186497/ha and 0.99), 7730 (rupees 180860/ha and 0.97), HeemSohna (rupees 172185/ha and 0.91 ) and Manisha (rupees 158505/ha and 0.85 ). The rest of the entries were found to be non-profitable (Table 3).

It is concluded that different tomato cultivars behaved significantly different from each other concerning various parameters. Among tested cultivars, Red Gold and RK 123 resulted in the highest production. Varieties were found superior in terms of fruit quality as compared to hybrids. The results concluded that organic regime gave the best production and quality produce and also organic tomato management is encouraged due to various advantages such as food safety, free from any chemical fertilizers and environment friendly.

\section{Acknowledgements}

The authors are highly thankful to the Indian Council of Agricultural Research, New Delhi, India for providing financial help under the Network Project on Organic Farming.

\section{References}

Abrar, H.S., Shams, U.I., Noor, U.I. and Safdar, H. 2011. Evaluation of two nutrient solutions for growing tomatoes in a noncirculating hydroponics system. Journal of agriculture, 27:558-557.

Ahmad, F., Khan, O., Sarwar, S., Hussain, A. and Ahmad, S. 2007. Performance evaluation of tomato at high altitude. Sarhad J Agric 23: 581-585.

Ahmad, R.., Sharma, J.P., Nabi, A. and Chopra, S. 2012. Germplasm evaluation for yield and fruit quality traits in tomato (Solanum lycopersicon L.). African Journal of

Agricultural Research, 7:6143-6149.

AOAC. 1975. Official Methods of Analysis of the Association of Official Analytic Chemist. (Ed. William Horwitz). Benjamin franklin station, Washington, DC.

Brady, K. 2011. Yield and quality performance of eleven open pollinated and three hybrid tomato cultivars grown under organic management in Lajas Puerto Rico. MS Thesis, Department of Agricultural Education, University of Puerto Rico, San Juan, PR China.

Colley, M. and Myers, J. 2007. On-farm cultivar trials: A guide for organic vegetable, herb, and flower producers. Organic Seed Alliance, Townsend, WA, USA.

Durvesh, K. and Singh, D. K., 2006, Performance of commercial hybrids of tomato. Progressive Horticulture, 38: 100104.

Falak, N., Ihasn, U.I., Syed, A., Abdus, S. and Abdur, R. 2011.Studies on the growth, yield and nutritional composition of different tomato cultivars in Battal valley of Khyber, Pakistan. Sarhad Journal of Agriculture, 27:570-571.

Giovannucci, E., Rimm, E.B., Liu, Y., Stampfe, R.M.J. and Willett, W.C. 2002. A prospective study of tomato products, lycopene, and prostate cancer risk. J Natl Cancer Inst 94: 391-398

Guold, W.A. and Berry, S. 1972. Tomatoes for canning. Outdoor Crop Res., Agric. Develop. Centre Ohio, USA.

Gupta, A., Sehgal, S. and Kawatra, A. 2011. Physical-chemical properties and nutritional evaluation of newly developed tomato genotypes. Journal of Food Science, 7:167-172.

Hossain, M. M., Shahjahan, M., Salam, M. A. and Begum, M. A. 2002. Screening of brinjal varieties and lines against brinjal shoot and fruit borer, Leucinodes orbonalis Guenee. Pakistan J. of Biological Sci. 5(10): 1032-1040. 
Jamala, G. Y., Boni1, P. G., Abraham P. and Musa, A. M. 2011. Soil status and yield response of different varieties of okra (Abelmoschus esculentus (L.) Moench) grown at Mubi floodplain, North Eastern, Nigeria. Journal of Agricultural Biotechnology and Sustainable Development, 3: 120 -125.

Masarirambi, M.T., Mhazo, N. T. Oseni, O. and Shongwe, V.D. 2009.Common physiological disorders of tomato fruit found in Swaziland. J. Agric. Soc. Sci., 5: 123-127.

Mehraj, H. S., Mutahera, M. Z., Roni, K. A., Nahiyan, S. M. and Jamal Uddin, A. F. M. 2014. Performance Assessment of Twenty Tomato Cultivar for Summer Cultivation in Bangladesh. Journal of Science, Technology and environmental informatics, 1: 45-53.

Moraru, C., Logender, L., Lee, T.C. and Janes, H. 2004.Characterization of 10 processing tomato cultivars grown hydroponically for the NASA advanced life support program, USA. Journal of Food Composition and Analysis, 7:141-154.

Murphy, K., Campbell, K., Lyon, S. and Jones, S. 2007. Evidence of varietal adaptation to organic farming systems. J Field Crop Res 102: 172-177.

Nandwani, D., Dennery, S., Forbes, V. and Geiger, T. 2014.Evaluation of four tomato varieties for commercial organic production in the U.S. Virgin Islands. Proc Caribbean Food Crops Soc., 50:139143.

Palada, M.C. and Davis, A.M. 2001. Yield performance of tomato cultivars grown under organic management systems. Proc Caribbean Food Crops Soc., 37: 154-160.

Palm, C.A., Myers, J. K. and Nandwa, S. M. 1997. Combined use of organic and inorganic nutrient sources for soil fertility maintenance and replenishment. Soil Science Society of America (Special Publication), 51: 193-217.

Santos, B.M., Vallad, G.E., Olson, S.M., Liu, G. and Simonne, E.H. 2013.Vegetable production in Florida. In: Santosh BM and Vallad GE (eds.) 2013 Vegetable production handbook for Florida. University of Florida. IFAS Extension, FL, USA pp: 1-5.

Singh, N.2011, Evaluation of Tomato genotypes under net house and open field conditions. M.Sc. thesis, Punjab Agricultural University, Ludhiana, India.

Thamburaj, S. 1998. Breeding for high quality vegetable. In: Souvenir of national Symposium on emerging Scenario in Vegetable. In: Souvenir of National Symposium on Emerging Scenario in Vegetables Research and Development, 12-14 Dec IIVR, Varanasi, India, pp.5359.

Tonfack, L.B., A. Bernadac, E. Youmbi, V. P. Mbouapouognigni, M. Ngueguim and A. Akoa. 2009. Impact of organic and inorganic fertilizers on tomato vigor, yield and fruit composition under tropical andosol soil conditions. Fruits, 64: 167177.

Unlu, H. and H. Padem. 2009. Effects of farm manure, microbial fertilizer and plant activator uses on yield and quality properties in organic tomato growing. Ekoloji, 19(73): 1-9.

Zhu W., Zhu L., Yang J., Xu T., Zhu W.M., Zhu L.Y., Yang Z.J., and Xu T.W. 2003. Breeding of tomato variety Pohong 909 for multispan plastic greenhouse. Acta Agriculturae Shanghai, 19: 33-35.

\section{How to cite this article:}

Parmar, D.K., D.R. Thakur, R.S. Jamwal and Gurudevsingh. 2018. Evaluation of Tomato Cultivars for Yield, Profitand Quality Performance in an Organic Management System in North Western Himalayas, India. Int.J.Curr.Microbiol.App.Sci. 7(10): 498-506. doi: https://doi.org/10.20546/ijcmas.2018.710.054 